\title{
Lumen
}

Selected Proceedings from the Canadian Society for Eighteenth-Century Studies

\section{Fathers as Monsters of Deceit: Robinson's Domestic Criticism in The False Friend}

\section{Eleanor Ty}

Volume 14, 1995

URI : https://id.erudit.org/iderudit/1012516ar

DOI : https://doi.org/10.7202/1012516ar

Aller au sommaire du numéro

Éditeur(s)

Canadian Society for Eighteenth-Century Studies / Société canadienne d'étude du dix-huitième siècle

ISSN

1209-3696 (imprimé)

1927-8284 (numérique)

Découvrir la revue

Citer cet article

Ty, E. (1995). Fathers as Monsters of Deceit: Robinson's Domestic Criticism in The False Friend. Lumen, 14, 149-158. https://doi.org/10.7202/1012516ar d'utilisation que vous pouvez consulter en ligne. 


\section{Fathers as Monsters of Deceit: Robinson's Domestic Criticism in The False Friend}

'Your father, Gertrude, was a monster of deceit, a false friend, and an enemy to virtue.' $(2: 49)^{2}$

Mary Darby Robinson (1758-1800), actress, poet, novelist, playwright, and autobiographer, published at least six volumes of poetry, eight novels, and two plays ${ }^{3}$ between 1775 and 1800 . Today, however, she is a figure little-known to students of the eighteenth-century or Romanticism. After reading her poem 'Jasper' which appeared in the Annual Anthology for 1800, Samuel Taylor Coleridge wrote of Robinson: 'She is a woman of undoubted Genius. ... She overloads everything; but I never knew a human Being with so full a mind — bad, good, \& indifferent ... but full, \& overflowing. ${ }^{4}$ By all accounts, he appeared to have admired her greatly. He corresponded with her, and wrote 'A Stranger Minstrel' to her a few weeks before she died. In the last decade of her life, Robinson became an active member of the circle of English radicals which included William Godwin, Mary Wollstonecraft, Eliza and John Fenwick, and Robert Southey. ${ }^{5}$ The Reverend Richard Polwhele cites her as one of the 'Gallic freaks' and 'Unsex'd Females' in his satiric poem of 1798. ${ }^{6}$ Despite her numerous productions and her association with important literary and historical figures, she is still best known as 'Perdita,' the actress who attracted the attention of George, Prince of Wales (later George IV) and afterwards became his mistress for the brief period of one year (1780).

In this paper I want to consider Robinson as a writer rather than as an actress or ex-mistress of the Prince. In particular, I wish to explore her involvement with the radical side of the "war of ideas" raging in England in the 1790s. Through an ideological reading of one of her last novels, The False Friend: A Domestic Story (1799) in relation to her essay, Thoughts on the Condition of Women, and on the Injustice of Mental Subordination $(1799),{ }^{8}$ I want to examine her engagement with feminist issues and Burkean politics. Like Mary Wollstonecraft, whom her heroine calls a 'champion' of our sex (False Friend 2:78), Robinson distrusted Edmund Burke's belief in patriarchy, his unquestioned elevation of the male as 
the 'monarch' of every British household. While in Condition of Women she boldly asserts that women 'are not the mere appendages of domestic life, but the partners, the equal associates of man' (3), in her novel The False Friend, the strong feminist stance is muted. The novel seems to be couched in the language of sensibility and its Gothic elements seem to be unnecessarily exaggerated. However, it is the very discrepancy between the powerful authority of father figures and the helplessness of the languishing virgin daughter which highlights the vulnerability of women. The fact that almost every patriarchal figure encountered by the heroine Gertrude turns out to be a monster, a 'false friend' and a potential rapist suggests the precariousness of woman's situation. Gertrude's domestic story, with its overtones of incest, its plot of abduction, imprisonment, and forced marriage, becomes a political statement about the ways in which the role of the father and, by analogy, all male roles of authority could be misused.

Although he is tyrannical, the patriarch in The False Friend remains the all-encompassing and dominating figure for the daughter. The predominance of the father-daughter or of a powerful male and helpless female relationship is in many ways indicative of a revealing pattern in Robinson's own life, as well as in her other works. Robinson had a series of relationships with promising men who turned out to be disappointing. Her husband, Thomas Robinson, who pretended to be gentleman of substance when he courted her, turned out to be a penniless bastard. He spent money recklessly, kept a mistress, and the couple ended up in debtors' prison. After less than a year, the Prince of Wales who, at one point had sent her a miniature of himself with the words, 'Je ne change qu'en mourant' and 'Unalterable to my Perdita through life,' left her for another woman, Mrs. Armistead, Robinson's former maid at Drury Lane. He never honoured his bond of $£ 20,000$ which he gave her, and left her without a career, and badly in debt. ${ }^{9}$ After spending more than a decade with her, Colonel Banastre Tarleton, who gambled heavily, left her in 1797 to marry a twenty-two year old heiress. ${ }^{10}$ By the late 1790 s, Robinson, paralyzed from the waist down, turned increasingly to writing as a means of consolation and financial support for herself, her daughter, and her widowed mother. ${ }^{11}$ Her last works reflect the disillusionment with, and yet a strange tenacious desire for, the ideals of domesticity and male authority figures.

In The False Friend for example, she creates a compelling patriarchal figure, Lord Denmore, who reassuringly tells the heroine, 'I will be your friend, your protector' (2:53). Yet he abandons Gertrude to her excessive sensibility, her naiveté, and to the machinations of fortune hunters and Gothic seducers for most of the novel. Like Mary Wollstonecraft in The Wrongs of Woman; or, Maria (1797), ${ }^{12}$ Robinson seems to be working out 
her ambivalent feelings toward what Mary Poovey, in another context, calls 'romantic idealism, ${ }^{13}$ and toward the expectations of the patriarchal family. The French Revolution of 1789 had inspired many radicals such as William Godwin, Mary Wollstonecraft, and Mary Hays to envision possibilities of change in the domestic as well as the public sphere. ${ }^{14}$ As Edmund Burke pointed out in his Reflections on the Revolution in France a 'revolution in sentiments, manners, and moral opinions ${ }^{\prime 15}$ had begun with the removal of the King and Queen of France from their palace in Versailles. Though Robinson did not openly show her support for the French Revolutionaries and their English sympathizers in the same way as Wollstonecraft did, in The False Friend she engages in the debate about the unavoidable changes in the nature of the family after the feminist controversy of the early 1790s. As Anne Mellor notes, 'many women writers of the Romantic era ... explicitly or implicitly advocated "family politics" as a political program that would radically transform the public sphere. ${ }^{\prime 16}$ Although The False Friend is subtitled 'a domestic story', it is thus very much concerned with large social issues such as the importance of affection in marriage, the imbalance of power in the family, the restricted sphere of women, and the responsibility of fathers and other figures of authority.

One pervasive theme of The False Friend is excessive female sensibility which was a subject that other writers of the 1790 s also treated. ${ }^{17}$ For Robinson, a woman's capacity to feel strong emotions and to be sympathetic was not altogether a negative quality, as it enabled her to perceive and to write about what others could not. However, sensibility became problematic when a woman was not able to get beyond feeling, or when the man upon whom her emotions were lavished was a worthless individual. ${ }^{18}$ At one point Robinson writes: 'If the proud could be taught to feel, how often would they blush at the miseries they inflict; how severely would compunction chastise them for the pangs which they teach the unfortunate to experience' (1:28). The heroine Gertrude, like Robinson herself, is praised for the 'delicacy of her sentiments, and the ingenuousness of her temper' (2:170). Yet this sensibility is what eventually leads to Gertrude's destruction as she notes: 'If we permit one object to influence every thought, to control every sentiment, to usurp an undivided dominion over our subjugated faculties ... whether that object be the lover or the friend ... he holds the reins of government over our senses' (2:181). Gertrude feels that she has become the dupe of her affections: 'I have nourished the poison till it has pervaded the innermost recesses of my heart, till it has infected the source of thought' (2:183).

The problem that Robinson illustrates in The False Friend and in her Thoughts on the Condition of Women is the discrepancy between a woman's capacity for powerful feeling and her inability to act according to her 
emotions or insights. This was a difficulty Mary Hays also explored in Memoirs of Emma Courtney (1796). While Hays intended her heroine Emma, the 'offspring of sensibility,' to be a singular 'warning,' rather than an 'example' for her readers, ${ }^{19}$ Robinson demonstrates that this problem was a more pervasive one than had been recognized. Robinson complains, 'Woman is to endure neglect, infidelity, and scorn: she is to endure them patiently ... she is to have no passions, no affections' (Condition, 77). In many instances in The False Friend, women become victimized because they are not able to deal with the lack of sensibility or with the deceit and indifference that Robinson sees as inherent in the fashionable world in which they live. The reality of women's lives does not meet their romantic expectations.

The repetition of the motif of 'false friends' in the novel suggests its importance. Aside from the heroine, other women are ruined by their misplaced affections for treacherous male figures. For example Gertrude says of Lady Denmore:

She was the victim of an unconquerable passion; the susceptibility of her mind was the ruin of her prospects, the bane of her reputation, and the undermining of her repose for ever ... she sacrificed all that was dear to woman, for a wretch who was practised in all that was despicable in man. (2: 314-16)

Similarly, another woman, Mary Ashgrove dies the 'victim' of her lover's 'falsehood' (4:73). When Mary Ashgrove realizes 'that all the affections of her heart were devoted to such a monster,' Gertrude remarks: 'there is no sensation more painful to the feeling mind, than the consciousness of idolizing a being, whose depravity should render him an object of detestation' (4:76). Implicitly these narratives within narratives, which seem to mirror each other, criticize a system wherein females are taught to place all their hopes upon unfaithful or false men. As Robinson says, 'woman, persecuted WOMAN, was taught to find her most relentless enemy, in that being, whom nature designed to cherish and protect her' (4:231).

Indeed the world that Robinson depicts in The False Friend is a world of 'destabilization and excess,' qualities that Elizabeth Napier associates with the Gothic, a form 'centrally concerned with problems of power, authority, and institutional oppression. ${ }^{20}$ The emotions aroused by Robinson's narrative are similar to those found in Gothic novels: a mixture of 'terror, artifice, and luxury,' heightened in 'moments of moral and spiritual decay, or of vulnerability and threat. ${ }^{21}$ Robinson shows the upper classes and aristocrats in a decadent state of irresponsibility where old values and traditions have eroded, replaced by dubious new ones. Lord Denmore speaks of a time 'when women were sincere, and men 
deserving! when wives made domestic happiness their study, and the honour of a husband's name was their certificate for virtue and discretion' (2:129). His wife reminds him, however, that in those days husbands 'did not pass their nights in clubs, their days with wantons; they were not ashamed of domestic virtue; neglectful of domestic happiness' (2:130). She complains that the new system teaches women to 'cherish deceit, indifference, vanity, contempt, and scorn' (2:130). Robinson's argument is that men are accountable for the 'destructive follies' and excesses of women: 'While they grow bold in the defence of vice, and timid in the cause of virtue, how can they hope that a weak, frail, feeling, and neglected woman has power to oppose deception, or to resist the pleasures of a world on which she is thrown defenceless?' (2:131-32).

This passage reveals the extent and limitations of Robinson's critique in the novel. While she lashes out against men who are unreliable and who misuse their authority, she does not extend her condemnation to include the way in which women are artificially made subordinates of men in her society. Here she still subscribes to the cultural construction of woman as the weak and frail being who must look to men for protection. In contrast, her attitude in Thoughts on the Condition of Women is more radical:

though it be readily allowed that the primary requisites for the ruling powers of man, are strong mental faculties; woman is to be denied the exercise of that intuitive privilege, and to remain inactive, as though she were the least enlightened of rational and thinking beings. What first established, and then ratified this oppressive, this inhuman law? The tyranny of man; who saw the necessity of subjugating a being, whose natural gifts were equal, if not superior to his own. (55)

The language used in the essay, words such as 'oppressive,' 'tyranny,' 'subjugating,' are reminiscent of Mary Wollstonecraft's revolutionary rhetoric. It shows Robinson's awareness of the sense of injustice in the construction of gender roles, and establishes her as a disciple of the better-known vindicator of woman's rights.

Throughout The False Friend, Gertrude seems unable to take control of her life. She is carried, sometimes literally, from one scene of terror or of humiliation to another. Perhaps one could see this as Robinson's exploitation of the conventions of the Gothic, an attempt to get on the 'bestseller list,' but I suggest that the damsel in perpetual distress becomes suggestive of woman's sense of helplessness and vulnerability in a society which accorded her little real economic and social power. Gertrude suffers from a series of mishaps: she is taken to Blonzely's and mistaken for a prostitute; people assume that she is Lord Denmore's 
mistress and mock her; the villain Treville, under whose care she is placed, attempts to seduce her a number of times. Because she is young and credulous, she becomes a target for the schemers: Blonzely tries to imprison her for debt; she is later kidnapped, and then narrowly escapes being raped by shooting at her assailant. Even the landlady, Mrs. Ferret, with whom she takes refuge, robs her of her possessions. It is as if the whole world has become a scene of persecution for Gertrude. Julia Epstein's remarks about violence in Burney's novels apply to Robinson's:

episodes of escalating violence and violation ... reveal a complicated relationship between decorous propriety and its potential for unexpected explosion .... In stunning episodes of unpreprared, gratuituous brutality, violence repeatedly shatters the apparently conventional social economy the novels' settings appear to subscribe to and protect. The characters' obsessions with social appearances derive from the possibility that violence may break through surface behaviors at any moment. ${ }^{22}$

For Robinson, the world is a cheat, where people wear masks to hide their inherent duplicity. Gertrude compares men to ravenous wolves who seek prey:

I have seen villains sanctioned by high patronage, even in the avowal of crimes, for which the lower orders of society would be eternally dishonoured. I beheld men, without sentiment, feeling, rectitude, or character, upheld in infamy; countenanced by the exalted, and even by the virtuous; their enormities concealed beneath the brazen mask of arrogance, and their violations of honour excused as the ebullitions of a glowing fancy' (2:239).

The aristocrats depicted in The False Friend are particularly callous and insensitive. For instance, Sir Hector believes that the world and all its inhabitants are created for his pleasure and gratification. 'We send a dozen black vagabonds up to Persia for our essences, and it is bad luck indeed, if out of twelve four does not return with his commission ... But they were created for our use, therefore we never care what becomes of them: there's plenty to be found; they overrun the country as thick as blackberries' (1:122).

This attitude of exploitation becomes even more frightening, as Sir Hector, who takes advantage of many women through the course of the novel, later acts as the Lord Justice before whom Gertrude has to plead her case. Gertrude meets him again as Lord Arcot who says half-jokingly that 'women were born to be slaves' (4:99). That such a man is deemed a worthy character, and put in offices of authority, becomes a telling 
comment on the society in which Robinson lived. Like Elizabeth Inchbald and Jane West, ${ }^{23}$ Robinson believed that the nobility and upper classes were not fulfilling their social obligations and therefore not deserving of their high positions. One servant in The False Friend remarks: 'One expects more from great people, you know, $\mathrm{Ma}^{\prime} \mathrm{am}$, than one does from common folks; and, truth can tell, we are often sadly disappointed' (4:196). Frequently in these novels which share a desire to reform society, common people are depicted as generous and intelligent beings while the rich and titled are shown as idle and depraved. For example, in The False Friend, while Gertrude takes refuge at Pew's parsonage, she notes the difference between the two worlds she has encountered: 'Here, simplicity and virtue grace the humble paths of life, attended by benevolence, and sustained by unaffected piety. There, all was dissimulation, vice, and folly; envy the predominating passion of the mind, and slander the promoter of every inquietude' (2:241-42).

Another way Robinson highlighted the problems she perceived with a society ruled by fathers is by revealing the instability and volatility of many male characters, especially those who wield power. Throughout the novel, the strong incestuous love between Lord Denmore and his adolescent ward Gertrude casts a malignant shadow upon the character of this otherwise respected father figure. Other examples of unscrupulous and capricious characters abound. People in the upper classes, for instance, frequently marry for selfish and ambitious reasons. Lord Melcomb 'wanted a rich wife; the Lady sighed for a titled husband' (1:62). Revealing the shakiness of these family units, most of the relationships described at the beginning of the first volume have dissolved by the fourth volume of the novel. Men elope with their friends' wives; many have extra-marital affairs. Late eighteenth-century fashionable society, as Robinson saw it, was a perpetual scene of chaos reflecting its confused moral values. The most distressing aspect of this for women was that they were more often than not the susceptible victims of male desire and whims. Often this vulnerability lead to death. Following the convention of Gothic and sentimental novels, Robinson depicts a number of deathbed scenes in The False Friend. But what is interesting is that most of the characters who die are women who languish as victims of misplaced passion.

In contrast to these languishing female characters, the males seem to thrive and live for conquest. In addition to the ubiquitous Sir Hector who later becomes Lord Arcot, there is Treville, whom Robinson modelled after her ex-lover Banastre Tarleton. After attempting to seduce Gertrude, intriguing with Miss Cecil, and eloping with Lady Denmore, Treville, whom the heroine compares to Lovelace (2:172), reappears under an assumed name. As Somerton, he becomes the lover of Mary 
Ashgroves who eventually dies of a broken heart. The changing identities of these men suggests their changeable natures. These erratic and irresolute males, Robinson shows, are not the solid and reliable upholders of domestic and public virtue as described by Edmund Burke. It is difficult to envision them as father figures of the ideal English family. In Thoughts on the Condition of Women Robinson noted with irony the ambivalent nature of this role: 'Man who professes himself her champion, her protector, is the most subtle and unrelenting enemy she has to encounter' (26). The False Friend, published in the same year, illustrates many of the feminist ideas found in her essay.

Ultimately, despite her virtuous intentions and character, the heroine in The False Friend is tormented and eventually overwhelmed by the machinations of those around her. Though she had earlier spoken of woman as man's 'equal' (2:78), she is unable to live up to her beliefs. She is not strong enough to dissociate her sensibility from her reason, or to resist the forbidden passion she feels. She asks: 'Is there any magic sufficiently strong to rescue us from their power over our senses? ... For I am the slave of such a fascination. Like the bird that is enthralled, I struggle for freedom, and the more I struggle the stronger I am entan-

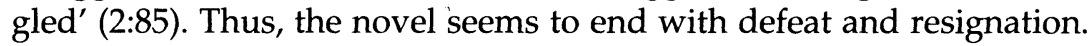
However, for feminist readers, it is an important and liberating work as it articulates in a powerful way a number of the injustices and wrongs suffered by women of the time. Reading Robinson's novel in the context of her other works and personal experiences, one sees the complex social, historical, and literary limitations which an eighteenth-century woman encountered in her attempts to grapple with many of the pervasive cultural ideologies of her time.

\section{ELEANOR TY}

Wilfrid Laurier University

\section{Notes}

1 My thanks are due to the Social Sciences and Humanities Research Council of Canada for a grant which enabled me to do research for this paper.

2 Mary Robinson, The False Friend: A Domestic Story, 4 vol. (London: T. N. Longman $\&$ O. Rees, 1799). All further references to this novel will be from this edition.

3 See Gary Kelly, English Fiction of the Romantic Period 1789-1830 (London and New York: Longman, 1989) 314; Roger Lonsdale, Eighteenth-Century Women Poets: An Oxford Anthology (Oxford: Oxford UP, 1990) 468-70; Marguerite Steen, The Lost One: A Biography of Mary (Perdita) Robinson (London: Methuen, 1937) 233; Virginia Blain, Isobel Grundy, and Patricia Clements, The Feminist Companion to Literature in English: Women Writers from the Middle Ages to the Present (New Haven: Yale UP, 
1990) 916; and Janet Todd, A Dictionary of British and American Women Writers 1660-1800 (Totowa, N.J.: Rowman and Littlefield, 1987) 270-72.

4 Samuel Taylor Coleridge, Collected Letters, ed. Earl Leslie Griggs, 6 vol. (Oxford: Clarendon Press, 1956-71) 1:562.

5 See Gina Luria, Introduction to Walsingham, or the Pupil of Nature (1797) by Mary Robinson, 4 vol. (New York: Garland, 1974) 7.

6 Richard Polwhele, The Unsex'd Females: A Poem (1798; New York: Garland, 1974) 7.

7 See Marilyn Butler, Jane Austen and the War of Ideas (Oxford: Clarendon Press, 1975).

8 Mary Robinson, Thoughts on the Condition of Women, and on the Injustice of Mental Subordination, 2nd ed. (London: T. N. Longman and O. Rees, 1799). Page references will be from this edition.

9 For her own account of this incident, see Mary Robinson, Memoirs of Mary 'Perdita' Robinson (1801), introduction by J. Fitzgerald Molloy (London: Gibbings and Co., 1895). Brief accounts are given in the introductory section of J. R. De J. Jackson, Romantic Poetry by Women: A Bibliography 1770-1835 (Oxford: Clarendon Press, 1993).

10 A full account of their relationship is found in Robert D. Bass, The Green Dragoon: The Lives of Banastre Tarleton and Mary Robinson (London: Alvin Redman, 1957).

11 See Judith Pascoe, 'The Spectacular Flâneuse: Mary Robinson and the City of London,' Wordsworth Circle 23 (1992): 165-71 and Cheryl Turner, Living by the Pen: Women Writers in the Eighteenth Century (London: Routledge, 1992).

12 Mary Wollstonecraft, Mary and the Wrongs of Woman (Oxford: World's Classics, 1976).

13 Mary Poovey, The Proper Lady and the Woman Writer: Ideology as Style in the Works of Mary Wollstonecraft, Mary Shelley, and Jane Austen (Chicago: U of Chicago P, 1984) 105.

14 I have discussed this at length in the introduction of my book, Unsex'd Revolutionaries: Five Women Novelists of the 1790s (Toronto: $U$ of Toronto P, 1993).

15 Edmund Burke, Reflections on the Revolution in France, ed. J.G.A. Pocock (Indianapolis: Hackett Publishing Co., 1987) 62.

16 Anne K. Mellor, Romanticism and Gender (New York: Routledge, 1993) 84.

17 For example, Jane Austen's Sense and Sensibility, Ann Radcliffe's The Mysteries of Udolpho, Jane West's A Gossip's Story, and Mary Hays' Memoirs of Emma Courtney. For further discussion of female sensibility in these authors, see Gary Kelly, Women, Writing, and Revolution, 1790-1827 (Oxford: Clarendon Press, 1993); Janet Todd, Sensibility: An Introduction (London: Methuen, 1986); Claudia Johnson, Jane Austen: Women, Politics, and the Novel (Chicago: U of Chicago P, 1988); and Eleanor Ty, Unsex'd Revolutionaries.

18 Gary Kelly notes that the 'liberal reforming element of the culture of Sensibility was clearly recognized as subversive by Anti-Jacobin British writers in the 1790s'; Gary Kelly, 'Jane Austen and the English Novel of the 1790s,' Fetter'd or free? British Women Novelists, 1670-1815, ed. Mary Anne Schofield \& Cecilia Macheski (Athens: Ohio UP, 1986) 286.

19 Mary Hays, Memoirs of Emma Courtney (1796; London: Pandora, 1987) xviii. 
20 Elizabeth R. Napier, The Failure of Gothic: Problems of Disjunction in an Eighteenth-Century Literary Form (Oxford: Clarendon Press, 1987) 45.

21 Napier, Failure of Gothic 46.

22 Julia Epstein, The Iron Pen: Frances Burney and the Politics of Women's Writing (Madison: U of Wisconsin P, 1989) 87.

23 Elizabeth Inchbald, Nature and Art, 2 vol. (London: G. G. and J. Robinson, 1796); Jane West, The History of Ned Evans (1796), 2nd ed., 4 vol. (London: G. G. and J. Robinson, 1797). 